\title{
THE SOCIAL ORIGINS OF MONEY: THE CASE OF EGYPT*
}

\author{
John F. Henry \\ Department of Economics \\ California State University, Sacramento
}

There are several ways to classify theories of money. For the purpose of this argument, the most telling distinction is between those theories that see money as a technical development, and those proposing that money is a social relationship. The former, generally following the thesis of Karl Menger (1892), promote the view that money is a thing, arising as a medium of exchange to reduce the transactions costs associated with inefficient barter arrangements. Such theories usually are associated with the "metallists," as it is normally some precious metal that arises to serve as the medium through which market exchange takes place (Goodhart, 1998). More important, this approach assumes an underlying equality among participants in the exchange relationship. As exchange must be voluntary in order for all parties to benefit, no coercive arrangements can exist that would negate freedom of choice.

Those who see money as a social relationship stress the significance of money as a unit of account in which obligations are both created and extinguished. Money, then, represents a relation between those who claim these obligations and those who must service those claims. Exchange is, at best, of secondary importance in such accounts, as markets need not exist for money to evolve: while money may indeed serve as a medium of exchange, this is not a necessary function (Ingham, 1996). Such theories necessarily connote (or at least imply) some underlying inequality, as those who claim obligations must be in a superior position to those who are obligated to the former. Otherwise, there would be no social reason to fulfill said obligations for any mechanism to enforce payment. (For elaboration of the differences in these approaches, see Bell, 2001; Smithin, 2000.)

The work of A. Mitchell Innes clearly falls into the second category. While it is true that much of his analysis is undertaken within the framework of a relatively modern exchange, or commercial, economy, and that he goes too far in equating the obligations of pre-civil societies with those of the present, the underlying foundation from which every main point in his argument flows rests on social obligations:

From the earliest days of which we have historical records, we are in the presence of a law of debt .... The sanctity of an obligation is, indeed, the foundation of all societies not only in all times, but at all stages of civilization; and the idea that to those whom we are accustomed to call savages, credit is unknown and only barter is used, is without foundation. From the merchant of China to the Redskin of America; from the Arab of the desert to the Hottentot of South Africa or the Maori of New Zealand, debts and credits are equally familiar to all, and the breaking of the pledged word, or the refusal to carry out an obligation is held equally disgraceful (Innes, 1913, p. 391).

Here, I want to subject the above accounts to historical examination, using ancient

Egypt as a case study. I will show that the development of money in the third millennium 
(1) is placed squarely in the transition from egalitarian to stratified society, (2) is intertwined with the religious character of early Egypt, and (3) represents a fundamental change in the substance of social obligations between tribal and class societies. While forms of social organization may seem similar, the appearance of money requires a substantial change in the character of social organization.

\section{A Brief History}

What do we know of Egyptian prehistory and its early, Pharaonic, history? Clearly, not as much as we would like. In analyzing and evaluating the early stages of Egyptian evolution, one must draw on limited archaeological evidence, comparative methodology, and theory. Despite whatever limitations exist, I believe we know enough to make sense of Egypt's social evolution and the relation of this evolution to money.

Through the middle of the fourth millennium, there is a rough-and-ready equality among the various populations who occupied the Nile Valley and the surrounding desert. The main economic activities of these peoples, as one would expect, were hunting, fishing, and gathering. Fishing may have been the most important activity, and we know that boat-building technology was sufficiently advanced by 7000 B.C. to allow fishing the main channel of the Nile (Hendricks and Vermeer, 2000, p. 35). With the Faiyumian population (or culture) of 5450-4400 (all dates are B.C. and approximate), agriculture begins to supplant these activities and eventually becomes the basis of subsistence in Lower (northern) Egypt. Barley, emmer wheat, and (perhaps) flax are grown and significant storage silos (granaries) measuring up to 3 feet deep and 5 feet in diameter are found in excavations of this period. In the contemporaneous Merinda culture of 50004000 , there is clear evidence of village life showing dwellings, streets, and separate work areas.

In the 4400-4000 period (that of the Badarian culture), the first evidence of agriculture in Upper (southern) Egypt is found. More important, remains from gravesites indicate the first evidence of inequality. Not only are there differences in the amount and type of grave goods found, including hammered copper, but graves of the wealthier inhabitants are physically separated from the more numerous resting-places of the majority. "This clearly indicates social stratification which still seems limited at this point in Egyptian prehistory, but which became increasingly important throughout the subsequent Naqada period" (Ibid., p. 40).

In the so-called Naqada period (4000-3000), inequality continued to evolve, and by 3000 B.C. there is clear evidence of kingship--the famous Narmer Palette of this date shows King Narmer ("Baleful Catfish"), identified in some accounts with the legendary Menes, unifier of all Egypt, wearing the crowns of both Upper and Lower Egypt. In the second phase of the Naqada period (3500-3200) there is "...a distinct acceleration of the funerary trend... whereby a few individuals were buried in larger, more elaborate tombs containing richer and more abundant offerings" (Midant-Reynes, 2000b, p. 53). We see a tremendous increase in the quality and variety of craft products, including copper tools replacing those of stone. "The picture of Naqada II society is thus revealed as a blueprint for the development of a class of artisans who were specialized in the service of the élite" (Ibid., p. 55). While it might be tempting at this point to locate the source of inequality in technological change, this would be inappropriate. In the north, the Maadi population, 
which practiced a pastoral-agriculture economy, appears to be as technologically advanced as those of the south, using copper as the dominant material in its tools. However, there is no evidence of stratification or hierarchical developments among this population.

In the Naqada III period (3200-3000), one sees evidence of kingship emerging. This period is labeled Dynasty 0 as it is unclear that there were kings proper, but grave goods now include gold and lapis lazuli, an imported good of high social value in later periods. As well, the Palermo Stone (c.2400), which traces Egyptian history from a mythical past to the point when the god Horus (the falcon, son of Osiris) gives the throne to Menes (Narmer) in 3000, indicates several kings or proto-kings during this period, including King Scorpion, a rather famous character in this chronicle.

What seems to have occurred in this one to two hundred year period is an expansion from the south (the Naqada) and gradual absorption of the northern populations with the Naqada arrangements predominating. This was probably the consequence, initially, of trade arrangements where the agricultural surpluses of the south were traded for manufactured goods of the north. The key element in these economic relations was control over the trade flows with the Levant (Middle East) which required large boats that could only be constructed with cedar coming out of what is now Lebanon. Among the goods coming in from outside Egypt were raw materials, in particular obsidian, and luxury goods (from the Egyptian perspective) that were used in a ceremonial function as grave goods for the wealthy. (See, Bard, 2000, p. 62 ff.; Bleiberg, 1995, pp. 1373-5; Midant-Reynes, 2000a, p. 236.) As well, it was at this time that the desert ecology changed, becoming increasingly arid making it difficult to continue providing the existing population with subsistence. This forced a migration of desert peoples into the Nile Valley.

It is worth observing at this point that this expansion from the south was not based on war. Though some historians struggle to interpret this process as accompanied by aggression--as, after all, orthodoxy would have it that people are "innately aggressive"-there is no evidence to support such an interpretation (see, Midant-Reynes, 2000a, pp. 237-46).

What do we see of substance during the period after 3000 indicating a change in the social character of Egyptian society? (And it can now properly be called "Egyptian.") Writing exists: clay tags on pots identify them as belonging to a king. A system of what can loosely be considered taxation, related to these tags, is in place. Memphis is clearly an administrative center and tombs around the city show strong evidence of different bureaucratic layers with size of tombs and amount and type of grave goods corresponding to rank. Foreign trade is controlled by the crown. There is a class of full-time craftsmen catering to the king and members of the administrative bureaucracy of the state. These artisans not only manufacture exquisite jewelry, statuary, vessels, tools, etc. (employing a level of artistry and decoration that go far beyond any utilitarian requirements), but also are engaged in the architectural advances required by the construction of elaborate tombs and other public buildings, in particular the temples. Lastly, we see the development of a state religion, centered around the king and celebrated through a mortuary cult. "Through ideology and its symbolic material form in tombs, widely held beliefs concerning death came to reflect the hierarchical social organization of the living and the state controlled by the king--a politically motivated transformation of the belief system with direct 
consequences in the socio-economic system" (Bard, 2000, p. 70). The (dead) king became the mediator between the living and the forces of the netherworld (nature), and represented a cosmic order in the world. The new religion, as will be shown, is of utmost importance for understanding the economic relations that the new Egypt exhibited and the significance of these relations for the creation of money.

During the Early Dynastic Period (3000-2625), the above developments continue to develop and solidify themselves as increasingly "normal." Anedjip (c. 2900) is the first king to assume the "nesu-bit" name (he of sedge and honey), signifying the combining of divine and mortal. Tomb construction became more elaborate and the amount, variety, and quality of grave goods continued to escalate, showing an enormous amount of waste. (One tomb was "saturated up to 'three feet' deep with aromatic oil. Almost 5,000 years after the burial, the scent was still so strong that it permeated the entire tomb" [Ibid., p. 73]). With the tomb complex of Djoser (c. 2650)--the step pyramids--we see the transition to the grand pyramids of the Old Kingdom.

In the Old Kingdom (2625-2130), we see the final steps in the transition underway since Naqada III. With Sneferu (2625-2585) the king is seen as having supernatural power and this is the first time we see the name of a king framed by the loop, signifying infinity. Re, the sun god, achieves supreme status over all other deities, and the cult of Osiris, associated with agriculture and yearly regeneration, is beginning its ascendancy. Dejedfre (2560-2555) becomes the first Pharaoh to use the title, "Son of the God Re," and to use Re in his own name, thus solidifying the relationship of the corporal king to the principal deity of the state religion. This was also the period of the building of the great pyramids, the most famous, of course, that of the Great Pyramid at Giza, built under Khufu (or Cheops) (2585-2560).

\section{The Story}

To explain the origins of money in Egypt, one must first explain how an egalitarian, tribal society is transformed into one of economic classes based on hierarchical (unequal) social structures.

Tribal society is a non-exchange, non-propertied society that follows the rule of hospitality--all had a right to subsistence that was collectively produced by its members on collectively held means of production. Such a society is nonpolitical in that no authority could exist independent of the population as a whole. Privilege, connoting superior-inferior relations, was absent as privilege is antithetical to equality. As such organizations operated on the basis of consensus, it would be inconceivable that the population would bestow privilege on some to the detriment of the majority.

In this society, there could be no debt. For every debtor there must be a creditor, and such a relationship is one of inequality with creditors having economic power over

debtors. Such an arrangement runs counter to the rule of hospitality, violating the right of some--debtors--to subsistence. True, tribal members were placed under various obligations--they must contribute to production, provide for the well being of their members, etc.--and debt is an obligation. But, such obligations were internal to the collective itself and of a reciprocal nature: all had obligations to all. There was no arrangement in which some would owe obligations to others in a non-egalitarian relationship. (See, Bell and Henry, 2001 for an extended treatment of these points.) Such 
a society conforms to what Karl Polanyi termed a system of "reciprocity" (Polanyi, 1957/1944, p. 47 ff.).

Up to about 4400 B.C., the evidence is that Egyptian populations lived in egalitarian, tribal arrangements. By the period 3200-3000, tribal society had been transformed into class society, and over the next 500 years the class structures became solidified around a semi-divine kingship. How can one explain such a transformation and what does this all have to do with money?

It is very clear that the transition was based on agriculture, and successful agriculture depended on some degree of control of the Nile. In the early stages of Egypt's agricultural history, the hydraulic system would obviously be very primitive, consisting mainly of catchment basins to store water during the inundation in order to allow irrigation during the dry season. Early success in these activities allowed the creation of a small and probably irregular economic surplus which made it possible to release some labor from direct production. But it was a thousand years from the dawn of agriculture to the first evidence of inequality. That is, while there was some agricultural specialization in the early period, tribal society held. In the period 4400-3000, increased stratification eventually broke the substance of tribal arrangements and inequality supplanted equality.

With early success, one would expect a concomitant growth in the division of labor. Early surpluses allowed some specialization which allowed greater surplus, and so on. Tribal populations recognized the importance of specialization, and while a good deal of such specialization was based on gender (men hunted, women gathered, etc.), they also practiced intra-gender specialization where some men, say, were recognized (and trained) as skilled hunters. At some point it would be recognized that some should specialize in hydraulic activities to increase the ability to control the Nile and thus allow even greater agricultural success. Given the traditional arrangements of tribal society, it is probable that members of a particular clan (or kinship group) were designated as hydraulic engineers. Such a group would organize the labor which was rotated out of other clans to construct the dykes, levees, and canals. (These were really ditches, as large-scale canals were only possible with the development of the Archimedean screw and the water-wheel which made it possible to lift water. This would place the advent of efficient canals in the Ptolemaic period, around 300 B.C. [Bowman and Rogan, 1999, p. 2].) They would also be in charge of the distribution of food, clothing, tools, etc. produced in the tribal villages and regularly sent to wherever the hydraulic system was being worked. And, they would gradually organize the increasingly regularized trade relations that the expansion of the hydraulic system required as the engineers would have the requisite knowledge of those requirements. This would also place them in the position of organizing the goods that served as exportables. In other words, these full-time engineers learned administrative skills beyond those required in the small communities of which tribal society consisted.

They also learned something else. As full-time specialists, they would develop skills and, in particular, knowledge that was not shared by all members of the community. And, as these populations became increasingly dependent on agriculture, they also become increasingly dependent on the specialized knowledge of the engineers.

Gradually, given the physical separation of the engineers for extended periods of time, and the monopoly over knowledge, it is probable that the income of the engineers rose faster than that of the average tribal member. All members would have seen a rise in their standard of living, but the engineers would have seen a relatively greater increase. It 
is very likely, and the evidence supports this, that in the early stages of this development, the difference in growth rates were miniscule. But, over centuries, even a $.05 \%$ difference would result in clearly observable absolute differences by the end of that time. This development would correspond to the Badarian period of 4400-4000.

The next stage of social evolution corresponds to the Naqada expansion resulting in the unification of Egypt by about 3000 B.C. As agriculture continued to develop, and knowledge of and technical advance required to control the Nile increased, it is obvious that at some point it would be recognized that the whole Nile Valley would have to be brought under some supra-tribal control. Local villages spread along the river could not be in a position to regulate the flow of water on which they were dependent. During years of low inundation, one village taking too much of the available water would endanger the production process of villages downstream. During periods of high inundation, failure to attend to needed repairs to the levees in one region would obviously affect not only that area but the whole valley beyond the breach (Bowman and Rogan, 1999, p. 34). We also know that in this period, there was a significant shift in the ecology of this region resulting in greater aridity, thus a reduced water flow (Nissen, et al., 1993, p. 1). Such a development would promote the need for control superseding any particular tribe's needs or abilities.

Thus, the engineer-administrators, originally based in one tribal organization and practicing egalitarian relations with other members of their tribe, would now be called upon to use their knowledge and skills to administer an extended physical area that would include any number of tribes. That is, the engineers increasingly saw themselves as independent of any particular tribe and were now responsible for the well being of a large population, independent of tribal status. Their job caused them not only physical separation, but social separation from their tribe. And not only social separation, but economic separation. They were now full-time specialists who controlled a significant flow of goods and labor and upon whom the majority of the population were dependent. The old collective rights and obligations of tribal society were being abridged and one group--the majority--was increasingly obligated to another. Inequality was growing and now becoming marked. In other words, economic classes were forming. This corresponds to the Naqada II period of 3500-3200.

By 3200-3000, this process of differentiation had hardened and we see the formation of a class society with religion as its unifying force and the dominant class-something of a feudal nobility--extracting economic surplus from the producing majority. Tribal reciprocity, though not totally abrogated (see below), was no longer the universal standard among the Egyptian populations, and was replaced by an economy of limited redistribution (in Polanyi's terms).

Before turning to the evidence supporting this interpretation, it is important to note several general considerations. In all this, the tribal population had to give its consent to what was unfolding--at least initially. A segment of an egalitarian society cannot (and would not) simply set itself up as a separate and unequal class de nova. Among other problems with such an interpretation, where would this segment get its idea of inequality? The idea must follow from the practice of inequality, and this practice would have to develop as a consequence of historical accident rather than conscious plan. In Egypt, the process took over one thousand years to reach fruition and was initially the result of tribal decisions, the long-run consequences of which could not be foreseen. 
Secondly, while the substance of tribal society was increasingly gutted, the emerging class had to maintain the forms of that organization. This was necessary in order to present the veneer that nothing fundamental had changed when, in fact, everything of substance had been altered. To keep the flow of surplus moving in its direction, the now-ruling class had to present the appearance that the older relations were intact. As well, though this is less important, tribal forms were what the nobility was accustomed to, and it is much easier to manipulate that with which one is familiar than to attempt to operate within a strange environment. Essentially, the façade of equality had to be maintained while inequality was growing and solidifying.

\section{The Evidence}

Pharaonic Egypt was organized around a system of phyles (as called by the Greek invaders). These social units were based on the clan structure of previous tribal society which continued to form the foundation of class society in the post-3000 B.C. period (Roth, 1991, and for most of what follows). Initially, the administrators of the economy were all related (kin) to the king. As the bureaucracy grew more extensive, non-clan individuals who had demonstrated competence in such activities were drawn upon to serve in the administration of the economic and political arrangements of the kingdom. This development became pronounced by the Fourth Dynasty (2625-2500) (Malek, 2000, p. 104). Strong evidence exists for an ongoing rotation of work in the service of the king by clan membership, including rotation through the various religious cults and royal mortuary temples. This rotation appears to have been organized around the principle in which a regular portion of the available (male?) labor would have been sent for yearly duties in the king's service. Indeed, the construction of the pyramids was undertaken precisely on this basis (Roth, pp. 207, 210-12). Last, the limited redistribution that existed in the Egyptian economy (see below) was organized on the basis of clan membership (Ibid., p. 209).

As the economy of the Nile Valley grew more extensive and increasingly interconnected, the organization of society by phyle ". . allowed the king to maintain a central authority by preventing the growth of rival institutions independent of royal control" (Ibid., p. 213). Essentially, the continued dependence on the original tribal structure permitted the continuation of the form of that structure even as the king and priesthood usurped the social control previously exercised by the various clans. In short:

The phyle system as an institution, then, played an important role in the development and success of Egyptian kingship in the Old Kingdom. The concept of a centralized government and its attendant bureaucracy . . . developed from the clans and village societies of predynastic Egypt. The evolution of the phyle as an institution parallels the development of the state. Emerging from its original character as a totemic system of clans that served to identify and regulate the personal and family loyalties that form the basis of a primitive society, it developed into a bureaucratic mechanism that organized large number of people for tasks as varied a 
building pyramids and washing and dressing the statue of a dead king (Roth, p. 216).

In order to maintain their position as a ruling class, the hydraulic engineers, now priests organized around a central authority, had to keep the flow of goods and labor moving in their direction. The older tribal obligations to provide the resources to construct and maintain the hydraulic system were now converted--in part--to maintain a privileged section of the population that no longer functioned, except in a ceremonial fashion, as specialized labor in the production process. How was this accomplished?

Tribal societies practiced magic in which the community exercised a collective relationship with their deceased ancestors who were believed to inhabit a spirit world that was part of nature. The deceased were to continue to fulfill their social obligations by communicating tribal commands to those forces of nature which could not be understood by pre-scientific populations. The hydraulic engineers subverted the substance of tribal magic while maintaining its form in elevating the king to a position of authority in communing with nature.

Totemism differs from mature religion in that no prayers are used, only commands. The worshipers impose their will on the totem by the compelling force of magic, and this principle of collective compulsion corresponds to a state of society in which the community is supreme over each and all of its members. ... The more advanced forms of worship, characteristic of what we call religion, presupposed surplus production, which makes it possible for a few to live on the labour of the many (Thomson, 1949/1965, p. 49).

The importance of religion, embodied in the funerary institutions--in particular, the elaborate tombs knows as the pyramids--cannot be underestimated in understanding the process through which the flow of economic surplus was controlled and the relation of this control to money.

The king had been chosen and approved by the gods and after his death he retired into their company. Contact with the gods, achieved through ritual, was his prerogative, although for practical purposes the more mundane elements were delegated to priests. For the people of Egypt, their king was a guarantor of the continued orderly running of their world: the regular change of seasons, the return of the annual inundation of the Nile, and the predictable movements of the heavenly bodies, but also safety from the threatening forces of nature as well as enemies outside Egypt's borders (Malek, 2000, p. 100).

Signifying the new state of affairs was the temple which was not only "... an architectural expression of royal power, it was for them a model of the cosmos in miniature" (Goelet, 2002, p. 285). And, while the pharaohs were careful not to supplant the clan (magic) cults with the new centralized religion (until the ill-fated experiment of 
Akhetaten, that is), the pharaoh became ". . theoretically, the chief priest of every cult in the land" (Ibid., p. 288).

The state religion was structured around Re and Osiris, emphasizing continual renewal in a never-ending cycle of repetition. The ideological thrust was one of permanence and long-standing tradition. Thus, even as change took place and fundamental political innovations were introduced, ". . . (the) tendency for Egyptian kings (was) not to emphasize what innovations they were instituting, but rather to stress how they were following long traditions. .." (Ibid., p. 287).

In a social context, the engineer-priests presented the image that nothing fundamental had changed, given the continuation of various institutional features of tribal society. In substantial point of fact, the world had been irrevocably altered. But, until the class-hold of the priests was firmly entrenched, until sufficient time had past to separate this society from its tribal foundations, the priests had to maintain the myth that things had remained as they always had been--and always would be.

Essentially, the spirit world was converted to one of gods, and the control of nature, previously seen as a generally sympathetic force, was now in the hands of the priests. Nature itself became hostile and its forces, controlled by gods, required pacification through offerings. The king--the "one true priest"--and the priests placed themselves as the central unifying force around which continued economic success depended. In so doing, they could maintain the flow of resources that provided their enormously high levels of conspicuous consumption and wasteful expenditures that certified their status as envoys to the natural world.

The significance of religion in the origin and development of money and monetary relations cannot be underestimated. As Innes noted some ninety years ago:

The relation between religion and finance is significant. It is in the temples of Babylonia that most if not all of the commercial documents have been found. The temple of Jerusalem was in part a financial or banking institution, so also was the temple of Apollo at Delphi. The fairs of Europe were held in front of the churches and were called by the names of the Saints, on or around whose festival they were held. In Amsterdam the Bourse, was established in front of or, in bad weather, in once of the churches.

They were a strange jumble, these old fairs, of finance and trading and religion and orgy, the latter often being inextricably mixed up with the church ceremonies to the no small scandal of devout priests . . . (Innes, 1913, p. 397).

(For a fuller account on the relation among money, religion, and various other social institutions_-including prostitution—see, Kurke, 1999.)

Under the new social organization, tribal obligations were converted into levies (or taxes, if one views this term broadly enough). The economic unit taxed was not the individual but the village (Eyre, 1999, p. 44). As well, the king and priests did not arbitrarily assign a tax level on the village, but tax assessors and collectors (scribes) met with the village chief who would assemble the village council to negotiate the tax (Ibid., p. 43). This appears to have been done on a biennual basis known as "counting of cattle," a census that also served as the dating for the various reigns of the king (Shaw, 2000, pp. 4-5; Hornung, 1999, p. 7). Should a village renege on its obligation (default), the chief 
responsible for the collection of taxes could be flogged by the scribes (Eyre, 1999, p. 40). Note that such a punishment makes the chief responsible to the priests rather than to the clan, further eroding the substance of tribal relations. Supervising all the local or regional scribes, and assuring both competence and honesty in this process, was a vizier who exercised central authority in the name of the king (Ibid., p. 43; Strudwick, 1985). It should be noted that in the elaborate bureaucratic structure that developed by the fifth dynasty, viziers served as the connecting link among the Overseers of the Granaries, of the Treasury, and of Labor (Strudwick, pp. 258, 275-6). These were the most important departments of the bureaucracy and, given the above argument, it is clear why there should be some interconnection among them. And, there is some evidence that the Overseer of the Treasury bore a religious title (rnnwtt) (Ibid., p. 283).

The economic surplus collected in the form of taxes was directed toward the priests who then redistributed some portion through the various levels of the bureaucracy, the temple artisans, and the workers who labored on the various religious and hydraulic projects. Hence, Egyptian society (along with others of this type) can be labeled an economy based on "redistribution" (Polanyi, op. cit.). However, it is important not to misunderstand the nature of this term. Such economies did not engage in full redistribution as it would defeat the whole purpose of such an economy if all production were to be first directed to the center, then flow back through all segments of society in some elaborate redistribution system. Not only would such a system be markedly inefficient, but what would be the point? Rather, only a portion of the economic surplus, produced by the majority of the population, would flow to the center, and this share of output would then be apportioned among the minority segments of society as stated above. The priests, of course, would claim the lion's share.

While tribal society clearly had been abrogated in the economic relationship between clans and members of the priestly class, it continued to hold at the village level, though in attenuated form. In the Old Kingdom and through much of the New Kingdom (c. 1569-1076), "mutual aid" (reciprocity) persisted (Bleiberg, 2002, p. 257). Even when evidence on loans--debt and credit--begins to appear, such loans cannot be viewed as equivalent to those of modern times. Interest was not charged; no hierarchical relationship existed where some were in debt to others. Rather, loans were granted in time of need to tide over the beleaguered party, and individuals were both "debtors" and "creditors" concurrently. Where interest seems to be charged, this was in actuality a penalty for late payment and was determined by social status--a non-egalitarian, thus, non-clan relationship (Goulet, 2002, pp. 281-2). The loan agreement was oral, indicating a high degree of social cohesion. Indeed, these "contracts" are difficult to categorize as loans. Rather, they should be seen as a continuation and modification of tribal hospitality where clan members were guaranteed subsistence. (See Bleiberg, 2002 on the above.)

In addition to the portion of the surplus collected now as taxes, the king also collected royal gifts as a form of tribute from foreign populations. As the goods that formed this income could be in the same form as the income that flowed from the internal population, but was the property of the king proper, it had to be kept apart from the internally generated income (Bleiberg, 1996).

All this required the development of an elaborate accounting system through which both assessments and payments could be recorded, and royal gifts could be kept separate from taxes. 


\section{Money In Egypt}

At some early point in the Old Kingdom, the growing complexities of the new economic arrangements required the introduction of a unit of account in which taxes and their payment could be reckoned and the various accounts in the treasury could be kept separate and maintained. This unit was the deben (and its fractional denomination, the shât--1/12 of a deben). (In the New Kingdom, 1550-1070, the qat--1/10 of a deben-replaced the shât.) The deben was a unit of weight, initially equated to 92 (or 91) grams of wheat. Later, but still in the period of the Old Kingdom, copper replaced wheat as the "thing" with which the deben was associated, and still later--in the Greek period--gold and silver became the "thing." Regardless of the particular object, however, the unit of weight remained 92 grams.

The fact that the deben bore no relation to and specific object, but referred to an arbitrary unit of weight only, is a certain indication that Egyptian money was decidedly not based on some "intrinsic value." What was true for Egypt remains true for all money (Mitchell, 1913, passim).

A few surviving contracts, mainly from the New Kingdom, demonstrate that goods were then valued in terms of the deben (and labor services in the pyramid cities determined by the deben value of consumption goods), but no debens ever changed hands (Bleiberg, 1996, p. 26; Grierson, 1977, p. 17; Ifrah, 2000/1981, pp. 72-4). Administered price lists were established, but the Egyptians had no coinage until the Ptolemaic period of the last three centuries, B.C. Basically, the scribes (and increasingly other sections of the population) maintained their accounts in the decreed unit of account, but payments were made in goods. "Such divergences between the money in which prices are reckoned and the commodities in which debts are discharged represent ... . a fairly common phenomenon in history (Grierson, 1977, p. 17). In other words, money does not originate as a medium of exchange but as a unit of account (and something of a store of value with regard to the king's treasury), where the measure of value is arbitrarily specified by decree, and goods and services of various qualities and quantities can then be assigned a monetary value to allow a reasonable form of bookkeeping to keep track of tax obligations and payments and to maintain the separate accounts of the king. It should also be noted that the deben did not serve as means of payment (as with modern money), but did function as the means (or measure) through which payment was made (following Grierson, above).

Now, the process through which this (or any) unit of account was developed was a necessarily difficult one.

Units of value, like units of area, volume, and weight, could only be arrived at with great difficulty, in part because natural units are absent, in part because of the much greater diversity of commodities that had to be measured and the consequent difficulty of finding common standards in terms of which the could reasonably be compared (Grierson, 1977, p. 18).

And money as simply a non-tangible abstract unit in which obligations are created and discharged, while it may appear obtuse to a modern economist, should not be all that 
difficult to comprehend. After all, we use on a daily basis and number of such abstractions:

The eye has never seen, nor the hand touched a dollar. All that we can touch or see is a promise to pay or satisfy a debt due for an amount called a dollar. . . What is stamped on the face of a coin or printed on the face of a note matters not at all; what does matter, and this is the only thing that matters is: What is the obligation which the issuer of that coin or note really undertakes, and is he able to fulfill that promise, whatever it may be?

The theory of an abstract standard is not so extraordinary as it at first appears, and it present no difficulty to those scientific men with whom I have discussed the theory. All our measures are the same. No one has ever seen an ounce or a foot or an hour. ... We divide, as it were, infinite distance or space into arbitrary parts, and devise more or less accurate implements for measuring such parts when applied to things having a corporeal existence. ...

Credit and debt are abstract ideas, and we could not, if we would, measure them by the standard of any tangible thing. We divide, as it were, infinite credit and debt into arbitrary parts called a dollar or a pound, and long habit makes us think of these measures as something fixed and accurate; whereas, as a matter of fact, they are peculiarly liable to fluctuations (Innes, 1914, p. 155).

While we don't have a good account of the process through which the unit of account was developed for Egypt, we can borrow from the more developed understanding of Mesopotamia as its general history accords nicely with that of Egypt.

In pre-agricultural Mesopotamia, there was little need for counting. Egalitarian societies practice reciprocity (the rule of hospitality) and there is no separate portion of society which needs to keep track of what it is owed or who owes it.

With the development of agriculture, one sees the introduction of clay token representing quantities of grain, oils, etc., and units of work. These tokens indicate a major conceptual leap as well as a need for systemization. "(T)he conceptual leap was to endow each token shape ... with a specific meaning" (Schmandt-Besserat, 1992, p. 161). Previously, any markings, such as those on tally sticks, could not be understood outside the context in which they were notched. With tokens, anyone conversant with the system could immediately understand their meanings. Moreover, as each token represented a particular object, it was now possible to systematically ". . manipulate information concerning different categories of items, resulting in a complexity of data processing never reached previously (Ibid.).

In the fourth millennium, accompanying urbanization or the formation of classes, these tokens assume new shapes, were of a higher quality indicating production by specialized craft workers, and featured lines and marks which required the development of writing and reading skills. Writing emerges from bookkeeping (Ibid., pp. 165-6). The marks are designed to solve the technical problem of storage and cumbersome tallying. When tokens were few in number, it was easy to both store and count them. With a growth in the number and types of token, a new system had to be developed to allow easy 
maintenance "of the books." Hence, a particular mark indicated so many tokens, and one mark replaced the physical presence of (say) ten tokens.

We also now begin to see tokens as part of the funerary goods found in gravesites, and these are only found in the graves of the wealthier members of society. Tokens are a status symbol, indicating a change from egalitarian to hierarchical society (Ibid., p. 171). Eventually, the production of tokens and their administration becomes a temple activity, associated with the system of taxation that has supplanted the older tribal obligations (Ibid., pp. 178-9). Writing--in this case the marks on the clay tokens that are the unit of account--was "invented to keep track of economic transactions" (Bleiberg, 1996, p. 22).

In Mesopotamia, accounts were maintained regarding agricultural yields, expenditures, and rights of disposition--the rights of usufruct--in terms of the unit of account. As well, rations of workers were configured in the same grain unit (Nissen, et al., pp. 64, 70, 82).

We observe the same sort of calculation in Egypt. A standard "wage" (ration) was ten loaves of standardized break and two jugs of beer. Other labor was rewarded at some multiple of this ration. As it is clear that man does not live by bread (and beer!) alone, and the multiple could be as great as fifty times the standard ration, such payments could not have been made literally in these two products, but rather represented a unit of account configured as so much grain (which is also the basic ingredient in beer) (Bleiberg, 1995, pp. 1379-80).

As well, loans--again, insofar as these arrangements can be considered loans--and their repayment were calculated in grain. As it is inconceivable that such economic relations would consist only of the exchange of grain no for grain later, particularly when no interest was changed, grain, again, should not be taken literally, but as a unit of account (Bleiberg, 2002, p. 259).

It is important to note that in Egypt (and this would accord with Mesopotamia and other areas) money was developed in a non-market, non-exchange economy. While some economic historians and anthropologists of a neoclassical persuasion diligently speculate that the Egyptian economy must have paralleled that with which we are now familiar, there is no evidence for exchange in the Old Kingdom. The Egyptians had no vocabulary for buying, selling, or even money; there was no conception of trading at a profit (Bleiberg, 1996, pp. 14, 23-4). It is very clear that there was no market in grains (Eyre, 1999, p. 53). A market economy (of a sort) and the monetization of the economy, including the production of coins, had to wait until Greek domination (Bowman and Rogan, 1999, pp. 25-6). Moreover, there is no evidence of private property in land in the Old Kingdom (Ibid., p. 24). Indeed, while there was some individualized farming on lands "leased" from temples and military estates, most agricultural production was undertaken on large plots collectively cultivated (Katary, 1999, p. 65), the output of which being designated for the use of the various segments of Egyptian society.

\section{Conclusion}

Egypt was not a monetary economy: production was not undertaken in order to "make money." But it certainly had money. And money was not a medium of exchange, but a social relationship. It was bound up with the transition from egalitarian to class society, the social requirement that the older tribal obligations had to be maintained in form 
though the substance of those obligations had now irrevocably been altered, and the funerary rituals that bound this class-fragmented society together. The ruling class, surrounding the semi-divine king, levied non-reciprocal obligations ("taxes") on the underlying population. These taxes had to be accounted for and a measure had to be developed to allow a reasonably systematic form of bookkeeping to maintain records of obligations and the extinguishing of those obligations. In Egypt, this unit of account was the deben, and it is important to note that the deben was an arbitrary standard that rested on a particular weight. And this weight remained the same regardless of whether it referred to grain, copper, or silver. Money has no value in and of itself. It is not "the thing" that matters, but the ability of one section of the population to impose its standard on the majority, and the institutions through which that majority accepts the will of the minority. Money, then, as a unit of account, represents the class relations that developed in Egypt (and elsewhere), and class relations are social relations.

A. Mitchell Innes's theoretical account, developed nearly a century ago and long ignored by economists, is in accord with the historical facts of the development of money in Egypt - and, as other contributors to this volume make clear, other places and other times. The neoclassical economists' argument is, on the contrary, found to be wanting. It is long past time to rethink our understanding of money, and to claim for Innes his rightful place among those theorists who advanced our understanding of this most important social institution called money. 
* This essay was written while I was Visiting Professor at the University of Missouri, Kansas City. I thank the faculty and staff of the economics department there for the gracious hospitality they extended me over the course of the academic year. A version of this paper was delivered at the Association for Institutionalist Thought conference of April, 2002 in Albuquerque, New Mexico. I thank Stephanie Bell, Edward Bleiberg, Chris Niggle, Jairo Parada, Pavlina Tcherneva, Eric Tymoigne, and L. Randall Wray for most helpful comments. Errors, of course, remain my own.

\section{References:}

Bard, K. (2000) "The Emergence of the Egyptian State," in Shaw, 2000a: 61-88.

Bell, S. (2001) "The Role of The State and the Hierarchy of Money, " Cambridge Journal of Economics" 25(2): 149-63.

Bell, S. and Henry, J. (2001) "Hospitality versus Exchange: the Limits of Monetary Economies," Review of Social Economy 59(2): 203-226.

Bleiberg, E., (1995) "The Economy of Ancient Egypt," in Sasson, et al., eds., Civilizations of the Ancient Near East, Vol. 3, New York: Charles Scribner's Sons: $1373-85$. . (1996) The Official Gift in Egypt, Norman, OK: University of Oklahoma Press. (2002) "Loans, Credit and Interest in Ancient Egypt," in Hudson, M. and De Mieroop, M., eds., Debt and Economic Renewal in the Ancient Near East, Bethesda, MD: CDL Press: 257-76.

Bowman, A. and Rogan, E. (1999) Agriculture in Egypt: From Pharaonic to Modern Times, Oxford: Oxford University Press.

Eyre, C. (1999) "The Village Economy in Pharaonic Egypt," in Bowman and Rogan: 3360.

Goelet, O. (2002) "Fiscal Renewal in Ancient Egypt: Its Language, Symbols, and Metaphors," in Hudson, M.and De Mieroop, M., eds., Debt and Economic Renewal in the Ancient Near East, Bethesda, MD: CDL Press: 277-307.

Goodhart, C. (1998) "The Two Concepts of Money: Implications for the Analysis of Optimal Currency Areas," European Journal of Political Economy 14: 407-32.

Grierson, P. (1977) The Origins of Money, London: The Athlone Press.

Hendricks, S. and Vermeer, P. (2000), "Prehistory: From the Paleolithic to the Badarian Culture," in Shaw, 2000a: 17-43.

Hornung, E. (1999) History of Ancient Egypt, Ithaca, NY: Cornell University Press.

Ifrah, G. (1981/2000) The Universal History of Numbers, New York: John Wiley and Sons.

Ingham, G. (1996) "Money is a Social Relation," Review of Social Economy, 54(4): 24375.

Innes, A. M. (1913) "What is Money," The Banking Law Journal, 30, May: 377-408. (1914) "The Credit Theory of Money," The Banking Law Journal, 31, Dec/Jan: 151-168.

Katary, S. (1999) "Land-Tenure in the New Kingdom: The Role of Women Smallholders and the Military," in Bowman and Rogan: 61-82.

Kurke, L. (1999) Coins, Bodies, Games, and Gold: The Politics of Meaning in Archaic 
Greece, Princeton, Princeton University Press.

Malek, J. (2000) "The Old Kingdom," in Shaw, 2000a: 89-117.

Menger, K. (1892) "On the Origin of Money," Economic Journal, 2(6): 239-55.

Midant-Reynes, B. (2000a) The Prehistory of Egypt, Oxford: Blackwell Publishers. 2000b "The Naqada Period," in Shaw, 2000a: 44-60.

Nissen, H., Damerow, P., Englund, R. (1993) Archaic Bookkeeping, Chicago: The University of Chicago Press.

Polanyi, K. (1957/1944) The Great Transformation, Boston: The Beacon Press.

Roth, A. (1991) Egyptian Phyles in the Old Kingdom, Chicago: The Oriental Institute of the University of Chicago.

Schmandt-Besserat, D. (1992) Before Writing, vol.1: From Counting to Cuneiform, Austin: University of Texas Press.

Shaw, I. (2000a) The Oxford History of Ancient Egypt, Oxford: Oxford University Press. (2000b) "Introduction: Chronologies and Cultural Change in Egypt," in Shaw, 2000a: $1-16$.

Smithin, J. (ed) (2000) What is Money, New York: Routledge.

Strudwick, N. (1985) The Administration of Egypt in the Old Kingdom, London: KPI.

Thomson, G. (1949/1965) Studies in Ancient Greek Society: The Prehistoric Aegean, New York: The Citadel Press. 